\title{
Effects of Meal Frequency on Growth Performance and Feed Efficiency of Two year-Old Mulloway (Argyrosomus Japonicus; Pisces : Sciaenidae) Reared in Tanks
}

\author{
Jeffrey A Guy ${ }^{1,2 *}$ and Stephen DA Smith ${ }^{1,2}$
}

${ }^{1}$ National Marine Science Centre, Southern Cross University, Coffs Harbour, New South Wales, 2450 Australia.

${ }^{2}$ Marine Ecology Research Centre, School of Environment, Science and Engineering, Southern Cross University, Lismore, New South Wales, Australia

\begin{abstract}
Two 4-week tank feeding trials were conducted with market size $(1.5 \mathrm{~kg}+)$ mulloway (Argyrosomus japonicus) to evaluate current commercial grow-out feeding practices related to short-term fasting. Growth performance, feed intake and efficiency were evaluated in seawater during spring 2013 (September-October, water temperature 18.22$21.97^{\circ} \mathrm{C}$ ) and autumn 2014 (May-June, $19.42-23.0^{\circ} \mathrm{C}$ ). Mulloway fed continuously in spring on a 6 day on -1 day off rotation, had the highest condition index (1.12), grew significantly $(P<0.05)$ faster $\left(S G R 0.35 \%\right.$ day $\left.^{-1}\right)$ and had better feed efficiency (FCE 76.97\%) than fish subjected to two different repetitive periods of fasting and satiation refeeding ( 1 day on -1 day off, SGR $0.24 \%$ day $^{-1}$, FCE $62.57 \%$; 2 days on - 1 day off, SGR $0.22 \%$ day $^{-1}$, FCE $58.24 \%$ ); despite these fish exhibiting hyperphagia. Feeding vigour and appetite was more pronounced in the 1 day on -1 day off than the 2 day on - 1 day off rotation. In autumn mulloway fed 5 days week $^{-1}$ had the lowest final weight $(1.63 \mathrm{~kg})$, grew significantly slower (SGR $0.26 \%$ day $^{-1}$ ), had poorer feed conversion (FCR 1.63) and condition (K 1.06) than fish fed 7 days week $^{-1}$ (final weight $1.74 \mathrm{~kg}$; SGR $0.44 \%$ day $^{-1}$; FCR $1.3, \mathrm{~K} 1.09$ ). The results of this study suggest that two-year-old mulloway do best under a constant feeding frequency while management actions, such as short-term fasting and not feeding on the weekend, will have a negative impact on fish growth and condition.
\end{abstract}

\section{Introduction}

Feeding is one of the most important activities in fish farming and comprises the choice of feed, control of ration size and temporal and spatial delivery to the fish [1]. Optimal delivery is essential for high survival and production rates, fast growth, good food conversion rates and water quality and economic viability [2]. Waste output is also closely related to the feeding regime and can be significantly reduced by using a suitable feeding frequency [3]. Determining the optimal feeding frequency of farmed species, however, has been difficult, as this can vary with fish species, size and culture system [4]. Generally smaller fish (fry and fingerlings) are fed smaller meals with greater frequency while once day ${ }^{-1}$ is usually sufficient for larger market-size fish. Some species, such as rainbow trout (Oncorhynchus mykiss) grow faster when fed four times day ${ }^{-1}$ compared with twice while the estuary grouper (Epinephelus tauvina) grow faster and show improved FCRs when fed every other day, compared to once day ${ }^{-1}$ or several times day ${ }^{-1}$. In post-smolt Atlantic salmon (Salmo salar) there was little or no effect on average growth with increased feeding frequency [5-7].

Current research, however, has focused only on hatchery and juvenile production stages [8-15] with the consequence that there are almost no baseline data for large fish and optimal feeding strategies for fish greater than $500 \mathrm{~g}$ to market size (1-3 kg live weight) remain largely unknown. Clearly, applied work is required to address this gap and future nutritional research priorities should focus on the validation of energy and feed requirements for market-size fish which consume the bulk of feed purchased [16].

Mulloway or jewfish (Argyrosomus japonicus) are a widely distributed temperate, euryhaline, carnivorous finfish of the family Sciaenidae, commonly known as drums or croakers [17]. Sciaenid species are becoming increasingly important to global aquaculture because they grow quickly, accept artificial food, are highly fecund with good food conversion ratios, can tolerate a wide range of salinity (5$35 \%)$, temperature $\left(5-35^{\circ} \mathrm{C}\right)$ and low oxygen levels, and can be grown at high stocking densities. This makes them an ideal candidate for farming in sea cages, coastal earthen ponds, and onshore recirculating systems $[18,19]$.

Production of mulloway in Australia and NSW was previously based on sea-cage culture $[20,21]$ but, more recently, an emerging industry is developing using aerated brackish-water prawn ponds in sub-tropical latitudes $\left(25-30^{\circ}\right)$ [22-26]. As is the case for any emerging aquaculture species, successful culture of mulloway will depend, in part, on the identification of proper feeds and feeding regimens for this species. The choice, however, of what feed to use for large mulloway and how to ration that feed to ensure its best use, is not currently available; although feeding strategies for hatchery and juvenile stages have been reported $[27,28]$. This has led to numerous unproven grow-out feeding practices by industry and our approach has been to investigate these while also using the farmer's choice of feed in the hope that this is more relevant and that industry may adopt new findings.

One practice, currently used by industry, is to suspend feeding for one or more days week ${ }^{-1}$ because feed accounts for $42.5 \%$ of the total variable costs [23]. This method (short-term fasting) has been used successfully in tilapia (Oreochromis niloticus) to reduce feeding costs with little effect on body composition [8]. Recent evidence also indicates that a break of one day in the fish's behavioural, digestive, and metabolic machineries appears favourable for diet utilization and growth [14].

*Corresponding author: Jeffrey A Guy, National Marine Science Centre, Southern Cross University, Australia, Tel: +61-2-6648-3913; E-mail: jeff.guy@scu.edu.au

Received November 26, 2015; Accepted March 09, 2016; Published March 11 2016

Citation: Guy JA, Stephen DA Smith (2016) Effects of Meal Frequency on Growth Performance and Feed Efficiency of Two year-Old Mulloway (Argyrosomus Japonicus; Pisces : Sciaenidae) Reared in Tanks. J Aquac Res Development. 7 419. doi:10.4172/2155-9546.1000419

Copyright: ( 2016 Guy JA, et al. This is an open-access article distributed under the terms of the Creative Commons Attribution License, which permits unrestricted use, distribution, and reproduction in any medium, provided the original author and source are credited. 
While significant amounts of feed (and labour) can be saved by adopting this method, there is currently no data on its efficacy, or its effect on growth and compensatory responses in mulloway. Alternatively, some farmers are convinced that feeding seven days week $^{-1}$ results in faster growth and a shorter production cycle and are reluctant to suspend feeding at all (pers. comm. Andrew Carroll, farm manager, Palmers Island Mulloway Pty. Ltd, 2014). To address these issues, two feeding trials were conducted to support better commercial feed management practices. The first investigated growth performance, feed efficiency and intake in response to periods of short term fasting and re-feeding (i.e., on alternate days) while the second investigated weekly feeding frequency $\left(5,6\right.$ or 7 days week $\left.{ }^{-1}\right)$.

\section{Materials and Methods}

\section{Commercial diet}

The feed used in all experiments was an off-the-shelf, $14 \mathrm{~mm}$, imported, formulated, extruded, fishmeal-based, sinking Japanese seabass (Lateolabrax japonicas) diet (Grobest Australia, Bray Investment Group Pty. Ltd.). Triplicate samples were analysed for proximate analysis by the Nutritional Biochemistry Laboratory, Coopers Plains, Brisbane, Queensland (Table 1).

\section{Fish collection and maintenance procedures}

Two-year-old mulloway were collected from a commercial fish farm and transported by road (1.5 hours) in an oxygenated (medical grade supplied at 1-2 $\left.\mathrm{L} \mathrm{sec}^{-1}\right) 900 \mathrm{~L}$ transport tank at a density of $75 \mathrm{~kg}$ $\mathrm{m}^{-3}$ to holding tanks at the National Marine Science Centre (NMSC), Charlesworth Bay, Coffs Harbour. Holding tanks were maintained in an outdoor undercover area and were subject to natural photoperiod and ambient climatic conditions. The tops of the tank were fitted with a dark green cloth to provide cover and shade. Fish were hand-fed the commercial diet $\left(10 \mathrm{~g} \mathrm{fish}^{-1}\right)$ at noon every other day $(\mathrm{M}, \mathrm{W}, \mathrm{F})$ for two weeks and two days prior to experimentation all feed was withheld. Fish were also treated twice (two days apart) with $200 \mathrm{mg} \mathrm{L}^{-1}$ formalin for one hour, two weeks prior to experimentation to eliminate ectoparasites [29].

Table 1: Proximate composition (dry matter basis) and pellet characteristics of the commercial diet ${ }^{1}$.

\begin{tabular}{|c|c|}
\hline Composition (\%) & Grobest diet \\
\hline Moisture $^{2}$ & $5.50 \pm 0.36$ \\
\hline Dry matter ${ }^{3}$ & $94.50 \pm 0.36$ \\
\hline $\mathrm{Ash}^{4}$ & $13.73 \pm 0.29$ \\
\hline Nitrogen $^{5}$ & $7.19 \pm 0.09$ \\
\hline Crude protein ${ }^{6}$ & $44.94 \pm 0.59$ \\
\hline Gross energy (MJ Kg ${ }^{-1}$ diet $)^{7}$ & $21.53 \pm 0.10$ \\
\hline Crude fat $^{8}$ & $17.33 \pm 0.85$ \\
\hline Crude fibre $^{9}$ & $1.17 \pm 0.06$ \\
\hline Weight $(\mathrm{g})^{10}$ & $0.74 \pm 0.01$ \\
\hline Diameter $(\mathrm{mm})^{11}$ & $14.04 \pm 0.03$ \\
\hline \multicolumn{2}{|c|}{$\begin{array}{l}{ }^{1} \text { Data are means ( } \pm \text { standard error) of triplicate samples. } \\
{ }^{2} 100 \text {-dry matter. } \\
{ }^{3} \text { Dry matter; by heating to constant weight at } 105^{\circ} \mathrm{C} \text { with Nitrogen using a LECO } \\
\text { Thermogravimetric Analyser. } \\
{ }^{4} \text { Ash; by further heating in the Thermogravimetric Analyser at } 600^{\circ} \mathrm{C} \text { in an } \\
\text { atmosphere of oxygen. } \\
{ }^{5} \text { Total Nitrogen; combustion method using an Elementar RapidN III analyser. } \\
{ }^{6} \text { Crude protein; total nitrogen multiplied by a factor, usually } 6.25 . \\
{ }^{7} \text { Gross energy; determined using a LECO Automatic Calorimeter. } \\
\text { } \text { Crude fat; soxhlet extraction using hexane for } 16 \text { hours. } \\
{ }^{9} \text { Crude fibre; AOAC method adapted for the Fibertec } 2021 \text { Fibrecap System. } \\
{ }^{10-11} \text { Weight and diameter; from three separate bags ( } 100 \text { pellets each). }\end{array}$} \\
\hline
\end{tabular}

\section{Tank stocking and design}

180 large mulloway with no deformities were stocked randomly into nine circular $3200 \mathrm{~L}$ tapered bottom polyethylene tanks at a stocking density 20 fish $\operatorname{tank}^{-1}$ with three replicate tanks for each feeding frequency (Table 2). At the time of stocking there were no significant differences in the mean weight, length and condition of fish $(\mathrm{P}>0.05)$ (Tables 3 and 4$)$. All tanks were supplied with their own 50 $\mathrm{mm}$ intake line for water and air and a two level external stand pipe allowed different water levels to be maintained. A $200 \mathrm{~mm}$ x $50 \mathrm{~mm}$ round air diffuser was positioned inside the tank, $30 \mathrm{~cm}$ above the 50 $\mathrm{mm}$ outlet hole, by fastening it to the metal frame above. There was no insternal stand-pipe and the flow rate was set at $16 \mathrm{~L} \mathrm{~min}^{-1}$ for the duration of the experiment. This work had ethics approval for research involving animals (SCU approval number ARA 12-13/01).

\section{Feed type, delivery and collection}

Fish were hand-fed to satiation the $14 \mathrm{~mm}$ commercial diet (Table 1) once daily at 12:00 hours, using the feeding regime detailed in Table 2. Satiation was determined when fish no longer fed vigorously mid-water and residual feed remained on the tank bottom. For each bag used 100 pellets (dry weight) were individually weighed to determine a mean pellet weight $(\mathrm{g})$. All uneaten pellets were collected by flushing the contents of the bottom external pipe into a coarse nylon net and then dried prior to counting following the procedure validated in Guy and Cowden[23]. Tanks were visually inspected to check that no pellets remained and pipes flushed a number of times to ensure they were empty.

\section{Water quality}

Water quality testing was conducted twice daily, 6 days week $^{-1}$ (am and pm) using a U-52 Horiba hand-held multi-meter. Parameters recorded were $\mathrm{pH}$ (Spring, range 7.89-8.26; Autumn, range 7.7-8.21) dissolved oxygen (Spring, 5.15-7.83; Autumn, 5.19-8.96 $\mathrm{mg} \mathrm{L}^{-1}$ ), salinity (Spring, 31.4-36.1; Autumn range 32.2-36.2 ppt), conductivity (Spring, 48.2-54.9; Autumn, 42.5-54.8 $\mathrm{ms} \mathrm{cm}^{-1}$ ), turbidity (NTU) (Spring, 0-2.0; Autumn, 0-5.5 $\mathrm{mg} \mathrm{L}^{-1}$ ) and total dissolved solids (TDS) (Spring, not measured; Autumn, $25.9-32.8 \mathrm{mg} \mathrm{L}^{-1}$ ). Water temperature was recorded in triplicate at hourly intervals using calibrated submersible temperature loggers (iBCod 22L, Thermodata Pty. Ltd.) (Table 2). Water samples $(100 \mathrm{~mL})$ were collected twice weekly (am and $\mathrm{pm})$ to determine the total ammonia nitrogen (TAN) (Spring, 0.17- 0.86; Autumn, 0.14$\left.0.71 \mathrm{mg} \mathrm{L}^{-1}\right)$ using a Palintest photometer 7100 . Un-ionised ammonia nitrogen (NH3-N) (Spring, 0.01-0.04; Autumn, 0.01-0.03 $\mathrm{mg} \mathrm{L}^{-1}$ ) was calculated from an online ammonia calculator using TAN, salinity, $\mathrm{pH}$ and temperature data. All water quality parameters were within the acceptable limits for marine finfish.

\section{Data/statistical analysis}

At the termination of each experiment (day 30), all fish in each tank were anaesthetized with AQUIS $\left(15 \mathrm{mg} \mathrm{L}^{-1}\right)$, individually counted, weighed and measured to determine survival rate, mean weight and length, condition index $(\mathrm{CI}=105 \mathrm{~W} / \mathrm{L} 3$ where $\mathrm{W}$ is weight and $\mathrm{L}$ is total length of the fish), absolute growth rate (AGR = (W2-W1) /t2$\mathrm{t} 1$ increment of weight W2-W1 over a known time ( $\mathrm{t})$; $\mathrm{g}$ fish ${ }^{-1}$ day $\left.^{-1}\right)$, specific growth rate $(S G R=100 \times($ loge final wt.-loge initial wt. $) /$ days; $\%$ day $\left.^{-1}\right)$, feed conversion ratio $(\mathrm{FCR}=$ dry feed intake $(\mathrm{g}) /$ wet weight gain $(\mathrm{g})$ ), feed conversion efficiency (FCE = wet weight gain $(\mathrm{g}) \times 100 /$ dry feed intake $(\mathrm{g})$ ) and protein efficiency ratio (PER = wet weight gain $(\mathrm{g}) /$ protein intake $(\mathrm{g})$ ). For statistical analysis the SPSS Version 22 software package (IBM) was used to conduct One Way ANOVAs with three repetitions ( $\mathrm{n}=3$ tanks, mean of 20 fish $\operatorname{tank}^{-1}$ ) for growth 
Citation: Guy JA, Stephen DA Smith (2016) Effects of Meal Frequency on Growth Performance and Feed Efficiency of Two year-Old Mulloway (Argyrosomus Japonicus; Pisces : Sciaenidae) Reared in Tanks. J Aquac Res Development. 7: 419. doi:10.4172/2155-9546.1000419

Page 3 of 6

Table 2: Design, season, water temperature $\left({ }^{\circ} \mathrm{C}\right)$ and survival $(\%)$ during mulloway tank feeding trials.

\begin{tabular}{|c|c|c|c|c|c|}
\hline Exp No: & Feed rate & Feed regime & Seasaon $^{1}$ (Year) & Water temp ${ }^{2}$ (range) & Survival \\
\hline \multirow[t]{2}{*}{1} & Satiation & $1 \mathrm{x}$ pm; every day & Spring & 19.99 & 100 \\
\hline & & 6 days week $^{-1}$, every two, every other day & $(2012)$ & $(18.22-21.97)$ & \\
\hline \multirow[t]{2}{*}{2} & Satiation & $1 \times \mathrm{pm} ; 5,6$ and & Aut/Winter & 21.00 & 100 \\
\hline & & 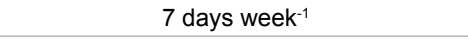 & $(2013)$ & $(19.42-23.00)$ & \\
\hline
\end{tabular}

${ }^{2}$ Mean of hourly readings from three data loggers randomly assigned to separate tanks for the duration of each experiment.

Table 3: Influence of feeding frequencies: every day six days week ${ }^{-1}$ ( 6 days on -1 day off), every other day ( 1 day on -1 day off) and every two days ( 2 days on -1 day off) at noon $(12-1 \mathrm{pm})$ on growth parameters, feed efficiency and condition of two-year-old mulloway (Argyrosomus japonicus) reared in tanks for 30 days. Data are means $( \pm$ standard error) of three replicate tanks (20 fish each) for each frequency. Means with different superscripts (a,b) within rows are significantly different $(P<0.05$; Tukey test). $P$ is probability value and *is significant.

\begin{tabular}{|c|c|c|c|c|}
\hline & Every day ( 6 on-1 day off) & Every other day (1 on-1 day off) & Every two days (2 on-1 day off) & p-value \\
\hline InitialWt. (kg) & $1.77 \pm .01^{\mathrm{a}}$ & $1.77 \pm .02^{\mathrm{a}}$ & $1.78 \pm .01^{\mathrm{a}}$ & 0.980 \\
\hline Final Wt. (kg) & $2.00 \pm .03^{\mathrm{a}}$ & $1.93 \pm .02^{\mathrm{a}}$ & $1.92 \pm .02^{\mathrm{a}}$ & 0.060 \\
\hline Initial $L^{1}(\mathrm{~cm})$ & $54.51 \pm .07^{\mathrm{a}}$ & $54.69 \pm .35^{\mathrm{a}}$ & $54.79 \pm .27^{\mathrm{a}}$ & 0.748 \\
\hline Final L (cm) & $56.27 \pm .21^{\mathrm{a}}$ & $56.12 \pm .38^{\mathrm{a}}$ & $55.87 \pm .08^{\mathrm{a}}$ & 0.562 \\
\hline Initial $\mathrm{Cl}^{2}$ & $1.10 \pm .01^{\mathrm{a}}$ & $1.08 \pm .01^{\mathrm{a}}$ & $1.08 \pm .02^{\mathrm{a}}$ & 0.719 \\
\hline Final $\mathrm{Cl}$ & $1.12 \pm .01^{a}$ & $1.09 \pm .01^{\mathrm{a}}$ & $1.10 \pm .01^{\mathrm{a}}$ & 0.180 \\
\hline TWG $(\mathrm{kg})^{3}$ & $4.7 \pm .41^{\mathrm{a}}$ & $3.24 \pm .35^{b}$ & $2.95 \pm .17^{b}$ & $0.020^{*}$ \\
\hline AGR $\left(\mathrm{g} \mathrm{fish}^{-1} \mathrm{day}^{-1}\right)^{4}$ & $6.54 \pm .57^{\mathrm{a}}$ & $4.49 \pm .49^{b}$ & $4.10 \pm .24^{b}$ & $0.019^{*}$ \\
\hline SGR $\left(\% \text { day }^{-1}\right)^{5}$ & $0.35 \pm .03^{\mathrm{a}}$ & $0.24 \pm .01^{\mathrm{b}}$ & $0.22 \pm .03^{\mathrm{b}}$ & $0.022^{*}$ \\
\hline Feed eaten $(\mathrm{kg})$ & $6.09 \pm .25^{\mathrm{a}}$ & $5.15 \pm .29^{\mathrm{a}}$ & $5.07 \pm .31^{\mathrm{a}}$ & 0.079 \\
\hline $\mathrm{FCR}^{6}$ & $1.31 \pm .06^{\mathrm{a}}$ & $1.61 \pm .09^{b}$ & $1.72 \pm .04^{\mathrm{b}}$ & $0.011^{*}$ \\
\hline FCE $(\%)^{7}$ & $76.97 \pm 3.89^{a}$ & $62.57 \pm 3.35^{b}$ & $58.24 \pm 1.24^{b}$ & $0.011^{*}$ \\
\hline PER $^{8}$ & $1.71 \pm .09^{a}$ & $1.39 \pm .07^{\mathrm{b}}$ & $1.29 \pm .03^{b}$ & $0.011^{*}$ \\
\hline
\end{tabular}

${ }^{1}$ Total length (L).

'2Fulton's condition index $(\mathrm{Cl})=10^{5} \mathrm{~W} / \mathrm{L}^{3}$ where $\mathrm{W}$ is the weight and $\mathrm{L}$ is the total length of the fish.

${ }^{3}$ Total weight gain $(\mathrm{kg})=$ (final weight -initial weight)

${ }^{4} \mathrm{Absolute}$ growth rate $\left(\mathrm{g} \mathrm{fish}^{-1} \mathrm{day}^{-1}\right)=(\mathrm{w} 2-\mathrm{w} 1 / \mathrm{t} 2-\mathrm{t} 1)$ increment of weight $\mathrm{W} 2-\mathrm{W} 1$ over a known time. (t) interval.

${ }^{5}$ Specific growth rate $\left(\%\right.$ day $\left.^{-1}\right)=100 \times$ (loge final wt.-loge initial wt. $) /$ days.

${ }^{6}$ Feed conversion ratio $=$ dry feed intake $(\mathrm{g}) /$ wet weight gain $(\mathrm{g})$.

${ }^{7}$ Feed conversion efficiency $(\%)=$ wet weight gain $(\mathrm{g}) \times 100 /$ dry feed intake $(\mathrm{g})$.

${ }^{8}$ Protein efficiency ratio $=$ wet weight gain/protein intake .

Table 4: Influence of feeding frequencies: 5,6 and 7 days $^{\text {week }}{ }^{-1}$ at noon (12-1 $\mathrm{pm}$ ) on growth parameters, feed efficiency and condition of two-year-old mulloway (Argyrosomus japonicus) reared in tanks for 30 days. Data are means ( \pm standard error) of three replicate tanks (20 fish each) for each frequency. Means with different superscripts $(a, b)$ within rows are significantly different $(P<0.05$; Tukey test). $P$ is probability value and * is significant.

\begin{tabular}{|c|c|c|c|c|}
\hline & 5 days week $^{-1}$ & 6 days week $^{-1}$ & 7 days week $^{-1}$ & $P$-value \\
\hline Initial Wt. (kg) & $1.50 \pm .01^{\mathrm{a}}$ & $1.50 \pm .01^{\mathrm{a}}$ & $1.50 \pm .01^{\mathrm{a}}$ & 0.815 \\
\hline Final Wt. (kg) & $1.63 \pm .01 \mathrm{a}$ & $1.69 \pm .01^{\mathrm{ab}}$ & $1.74 \pm .03^{b}$ & $0.015^{\star}$ \\
\hline Initial L ${ }^{1}(\mathrm{~cm})$ & $52.43 \pm .05^{\mathrm{a}}$ & $52.70 \pm .11^{\mathrm{a}}$ & $52.54 \pm .27^{\mathrm{a}}$ & 0.567 \\
\hline Final L (cm) & $53.47 \pm .09^{a}$ & $53.97 \pm .44^{a}$ & $53.98 \pm .81^{\mathrm{a}}$ & 0.459 \\
\hline Initial $\mathrm{Cl}^{2}$ & & & $1.03 \pm .02^{\mathrm{a}}$ & \\
\hline Final $\mathrm{Cl}$ & $1.06 \pm .01^{\mathrm{a}}$ & $1.07 \pm .01^{\mathrm{ab}}$ & $1.09 \pm .01^{\mathrm{b}}$ & $0.049^{*}$ \\
\hline TWG $(\mathrm{kg})^{3}$ & $2.66 \pm .23^{a}$ & $3.83 \pm .26^{\mathrm{ab}}$ & $4.76 \pm .71^{b}$ & $0.048^{*}$ \\
\hline AGR $\left(\mathrm{g} \mathrm{fish}^{-1} \text { day }^{-1}\right)^{4}$ & $4.03 \pm .35^{\mathrm{a}}$ & $5.80 \pm .39 a b$ & $7.21 \pm 1.08^{b}$ & $0.048^{*}$ \\
\hline SGR $\left(\% \text { day }^{-1}\right)^{5}$ & $0.26 \pm .02^{\mathrm{a}}$ & $0.36 \pm .02^{\mathrm{ab}}$ & $0.44 \pm .06^{b}$ & $0.049^{*}$ \\
\hline Feed eaten $(\mathrm{kg})$ & $4.32 \pm .22^{\mathrm{a}}$ & $5.28 \pm .12^{\mathrm{ab}}$ & $6.11 \pm .53^{b}$ & $0.028^{*}$ \\
\hline $\mathrm{FCR}^{6}$ & $1.63 \pm .07^{a}$ & $1.38 \pm .05^{\mathrm{ab}}$ & $1.30 \pm .07^{b}$ & $0.031^{*}$ \\
\hline $\mathrm{FCE}(\%)^{7}$ & $61.28 \pm 2.47^{a}$ & $72.31 \pm 3.29^{\mathrm{ab}}$ & $77.11 \pm 4.50^{b}$ & $0.047^{*}$ \\
\hline $\mathrm{PER}^{8}$ & $1.36 \pm .05^{\mathrm{a}}$ & $1.61 \pm .07^{\mathrm{ab}}$ & $1.71 \pm .10^{\mathrm{b}}$ & $0.047^{*}$ \\
\hline
\end{tabular}

performance and feed efficiency data. Means were compared using the Tukeys Honestly significant difference (HSD) method $(\mathrm{P} \leq 0.05)$.

\section{Results}

\section{Short term fasting and re-feeding}

Mulloway that were fed more consistently (6 days on - 1 day off), had the highest condition index $(1.12)$, grew significantly $(\mathrm{P}<0.05)$ faster (SGR 0.35\% day ${ }^{-1}$ ) and had better feed efficiency (FCE 76.97\%) than fish exposed to the two different repetitive periods of fasting and satiation re-feeding ( 1 day on - 1 day off, SGR $0.24 \%$ day $^{-1}$, FCE $62.57 \%$; 2 days on - 1 day off, SGR $0.22 \%$ day $^{-1}$, FCE 58.24\%) (Table 3). Mulloway responded to these periods of periodic food deprivation with increased feed intake and appetite; this hyperphagic response was greater in fish exposed to the 1 day on - 1 day off regime of than two days on - 1 day off (Figure 1).

\section{One or more days fasting per week}

Fish fed 5 days week ${ }^{-1}$ had the lowest final weight $(1.63 \mathrm{~kg})$, grew significantly slower (SGR $0.26 \%$ day $^{-1}$ ), had poorer feed conversion (FCR 1.63) and condition (K 1.06) than fish fed 7 days week $^{-1}$ (final weight $1.74 \mathrm{~kg}$; SGR $0.44 \%$ day $^{-1}$; FCR 1.3, K 1.09) (Table 4). Condition, growth, amount of feed eaten and conversion efficiency did not differ significantly $(\mathrm{P}>0.05)$ when fish were fed 6 days week $^{-1}$ instead of 7 days week ${ }^{-1}$ even though total weight gain was lower and less feed was eaten (Table 4).

\section{Discussion}

\section{Influences of short term fasting and re-feeding on mulloway performance}

The results of our preliminary study indicate that market-size mulloway exhibit hyperphagia when faced with repetitive periods of 
A
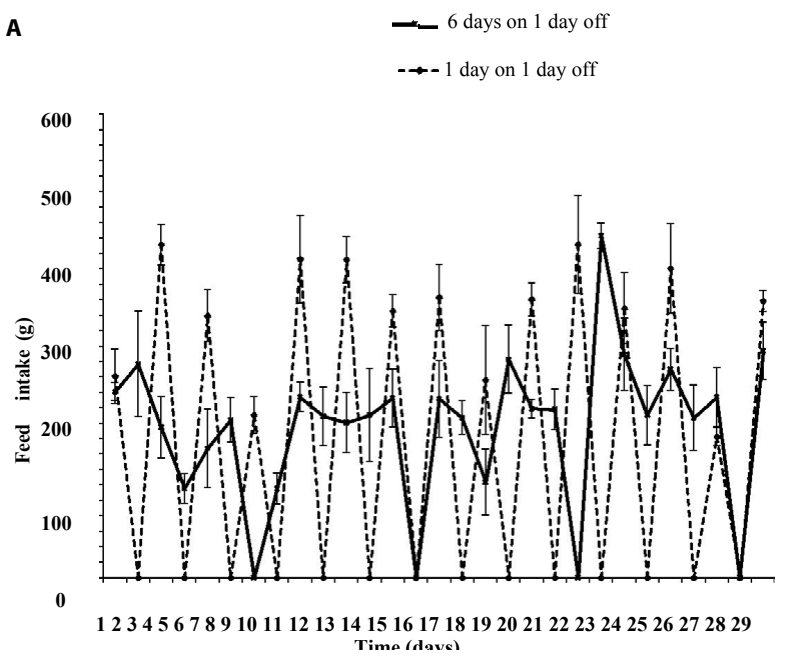

B

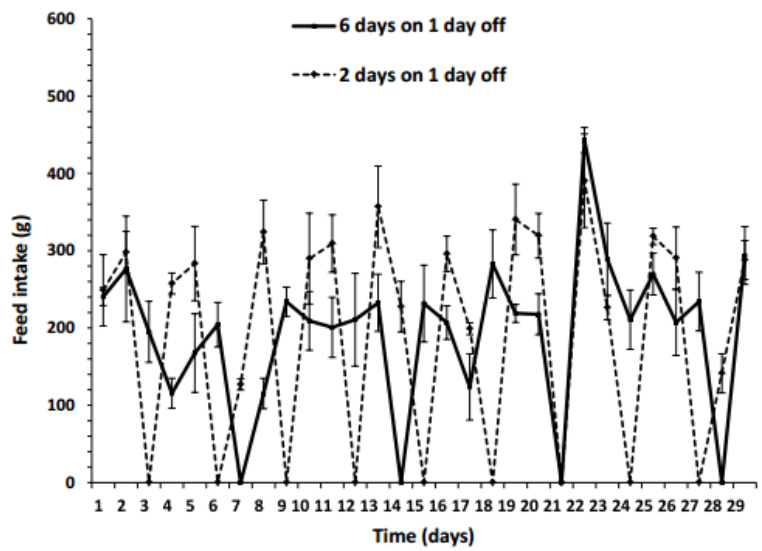

Figure 1: Daily feed intake of mulloway (Argyrosomus japonicus) subjected to two different repetitive periods of fasting and satiation re-feeding over 4 weeks. The more constant or regular feeding regime ( 6 days on -1 day off) is indicated by the thick solid line. Data are means \pm S.E. of three replicate tanks (20 fish each).

short-term food deprivation. Hyperphagia is a rate of food consumption significantly higher than that shown by fish that have been continuously fed [30]; in this study this occurred in the 6 days on - 1 day off rotation. This response was more pronounced in the 1 day on - 1 day off than the 2 day on- 1 day off rotation indicating that the prior history of feed intake, prior to deprivation, may have some influence on the amount of feed eaten, post deprivation. There is evidence for structural changes (hypertrophy of tissues) in the fish gut, which increase its gastric capacity, when fish are exposed to intermittent feeding [31]. For example, Peterson and Small [43] used Gastrointestinal (GI) index (weight of GI tract (g)/weight of fish (g) x 100) as a measure and found that the GI tract index decreased in NWAC103 catfish (Ictalurus punctatus) fed twice and three times daily, respectively, compared to fish fed only once a day: a similar trend was observed among the Norris catfish strain [32]. Similarly, reducing feeding frequency (to every other day) resulted in plaice (Pleuronectes platessa) developing larger stomachs than those fed more frequently [33]. The ability to enlarge the GI tract after feeding may represent a suite of adaptations that enable fish to maintain rates of nutrient and energy intake [34]. The extent to which animals recover lost body weight, however, has been reported to vary between studies [35].
In the case of mulloway, despite their compensatory response, growth and feed conversion was marginal. This has also been reported in channel catfish, gilthead sea bream (Sparus aurata) and pacu (Piaractus mesopotamicus), where partial compensation resulted in reduced growth and production, processing yield or an extended production cycle compared with daily feeding [36-38]. This is also the case with turbot (Scophthalmus maximus) which should be fed daily as even cycles of short periods of feed deprivation negatively affect growth and don't improve feed efficiency [39]. By contrast, other farmed species, such as rainbow trout, the Amazon fish matrinxã (Brycon amazonicus), hybrid sunfish (Lepomis macrochirus $\times$ L. gibbosus) and walleye (Sander vitreus) have shown to fully compensate for lost growth [40-43].

This is an important initial finding as mulloway farmers using short-term fasting to improve production efficiency will extend their production cycle. While this remains to be tested under commercial culture conditions, this initial work in tanks has been crucial in documenting this response and presents the first information on hyperphagia in mulloway.

One possible explanation for the lower growth rate and feed efficiency may be that excessive eating (overloading the stomach and intestine) decreases the efficiency of digestion and absorption, which limits the supply of energy for growth $[44,45]$. For example, in gilthead sea bream, increased feed uptake led to a rise in oxygen consumption [46] and such responses can decrease the efficiency of feed absorption by up to $15 \%$ [47-49] reported that when feeding rate exceeded $2 \%$ body weight day ${ }^{-1}$ in juvenile grass carp (Ctenopharyngodon idella) the apparent digestibility coefficient decreased quickly and growth was reduced. Negative effects have also been reported for African catfish (Clarias gariepinus) [50] and brown trout (Salmo trutta) [51]. Future work to monitor the apparent digestibility of the food, would provide more insight into the digestion and utilization of the feed at different levels of ingestion.

Another possible explanation for the reduced growth rate is that large mulloway are particularly sensitive to any disruption to their feeding rhythm. Fasting, as well as other stressors such as handling and hypoxia, are known to increase plasma cortisol, metabolites (glucose and lactate) and to trigger the release of catecholamines in many teleosts [52]. Recent investigations by Sánchez [53] with gilthead sea bream, indicate that the feeding cycle considerably influenced growth performance, behaviour, and cortisol and glucose levels. Here, fish fed randomly had lower growth rates and higher cortisol and glucose levels than fish that received food regularly and at a scheduled time. El Sayed et al. [54] also reported higher blood glucose levels in fasted pacu compared to control fish. Future work, to investigate the blood chemistry of mulloway, exposed to different fasting cycles is needed to address this issue.

\section{Influence of one or more days fasting per week on mulloway performance}

This study clearly demonstrates that large mulloway fed 5 days week $^{-1}$ had significantly poorer growth, condition and feed efficiency to those fed 7 days week $^{-1}$. This again supports the idea that market-size mulloway do best under a constant feeding regime and that management actions to save input costs, such as not feeding at the weekend (5 days week $^{-1}$ ), will have a negative impact on fish growth and condition. This has also been documented in rainbow trout and tilapia where fish fed 5 days week ${ }^{-1}$ had reduced growth [55]. However, the effects of food deprivation for one or more days week ${ }^{-1}$ on farmed fish have been variable. García-Mesa et al. [14] reported that meagre (Argyrosomus 
Citation: Guy JA, Stephen DA Smith (2016) Effects of Meal Frequency on Growth Performance and Feed Efficiency of Two year-Old Mulloway (Argyrosomus Japonicus; Pisces : Sciaenidae) Reared in Tanks. J Aquac Res Development. 7: 419. doi:10.4172/2155-9546.1000419

Page 5 of 6

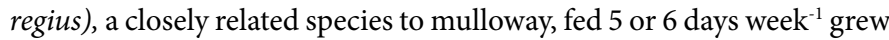
in a similar way to those fed every day; but concluded that the regime of 6 feeding days to 1 feed-deprivation day could be considered the most favourable in terms of growth rate and body composition. $\mathrm{Li}$, Robinson and Bosworth [37] reported that net production and amount of feed fed did not differ significantly $(\mathrm{P}>0.05)$ when fish were fed 6 days week $^{-1}$ instead of 7 days week ${ }^{-1}$ even though net production was lower and less feed was fed. Additionally, feeding channel catfish fewer than 6 days week $^{-1}$ lowered net production and feed fed even further [55].

In conclusion, in this set of experiments, we set out to determine if the current industry practice of restricting feeding, to provide economic benefits through reduced feed and labour costs, had merit. The results suggest that use of short-term fasting has limited application in mulloway grow out due to its negative affect on fish growth and feed conversion. Therefore, in order to obtain optimal outcomes, regular and constant feeding is recommended.

\section{References}

1. Talbot C, Corneillie S, Korsøen $\varnothing$ (1999) Pattern of feed intake in four species of fish under commercial farming conditions: implications for feeding management. Aquaculture Research 30: 509-518.

2. Alanärä A, Kadri S, Paspatis M (2007) Feeding management. Food intake in fish. Blackwell Science, Oxford: 332-353.

3. Wu Y, Han H, Qin J, Wang Y (2015) Effect of feeding frequency on growth, feed utilization, body composition and waste output of juvenile golden pompano (Trachinotus ovatus) reared in net pens. Aquaculture Research 46: 1436-1443.

4. De Silva S, Anderson T (1995) Fish nutrition in aquaculture. Melbourne: Chapman and Hall: 319.

5. Chua T, Teng S (1978) Effects of feeding frequency on the growth of young estuary grouper, Epinephelus tauvina (Forskål), cultured in floating net-cages. Aquaculture 14: 31-47.

6. Thomassen M, Fjæra S (1996) Studies of feeding frequency for Atlantic salmon (Salmo salar). Aquacultural Engineering 15: 149-157.

7. Başçınar N, Okumuş I, Başçınar N, Emiral Sağlam H (2001) The influence of daily feeding frequency on growth and feed consumption of raınbow trouth fıngerlings (Oncorhynchus mykıss) reared at $18.5-22.5^{\circ} \mathrm{C}$. The Israeli Journal of Aquaculture-Bamidgeh 53: 80-83.

8. Villarroel M, Alavrino J, Lopez-Luna J (2011) Effect of feeding frequency and one day fasting on tilapia (Oreochromis niloticus) and water quality. Israeli Journal of AquacultureBamidgeh 63: 1-6.

9. Takahashi S, Biller D, Criscuolo-Urbinati E, Urbinati C (2011) Feeding strategy with alternate fasting and refeeding: effects on farmed pacu production. Journal of Animal Physiology and Animal Nutrition 95: 259-266

10. Trushenski J, Rombenso A, Schwarz H, Bowzer J, Gause B et al. (2012) Feeding Rate and Frequency Affect Growth of Juvenile Atlantic Spadefish. North American Journal of Aquaculture 74: 107-112.

11. Li H, Robinson H, Oberle F, Lucas M (2012) Effects of Feeding Rate and Frequency on Production Characteristics of Pond-Raised Hybrid Catfish. North American Journal of Aquaculture 74: 142-147.

12. Asuwaju F, Onyeche V, Ogbuebunu K, Moradun H, Robert E, et al. (2014) Effect of Feeding Frequency on Growth and Survival Rate of Clarias gariepinus Fingerlings Reared in Plastic Bowls. Journal of Fisheries and Aquatic Science 9: 425-429.

13. Baloi M, de Carvalho C, Sterzelecki F, Passini G, Cerqueira V (2014) Effects of feeding frequency on growth, feed efficiency and body composition of juveniles Brazilian sardine, Sardinella brasiliensis (Steindacher 1879). Aquaculture Research 47: 554-560.

14. García-Mesa S, Suárez M, Rodríguez-Rúa A, Cárdenas S, García-Gallego $\mathrm{M}$, et al. (2014) Productive and physiological implications of different feeding frequencies in meagre Argyrosomus regius (Asso, 1801). Aquacultural Engineering 60: 6-13
15. Hayward R, Masagounder K, Clayton R, Morris J, Ali M (2015) Increasing growth and feed efficiency of Juvenile Walleye, Sander vitreus (Mitchill, 1818) through novel, subsatiation, restrict/feed cycles from late summer into fall. Aquaculture Research 46: 952-958.

16. Glencross $B$ (2006) The nutritional management of barramundi, Lates calcarifer - a review. Aquaculture Nutrition 12: 291-309.

17. Silberschneider V, Gray C (2008) Synopsis of biological, fisheries and aquaculture-related information on mulloway Argyrosomus japonicus (Pisces:Sciaenidae), with particular reference to Australia. Journal of Applied Ichthyology 24: 7-17.

18. Collett $P$ (2008) Toward the development of a rearing protocol for juvenile dusky kob, Argyrosomus japonicus (Pisces: Sciaenidae) Thesis. Rhodes University, South Africa.

19. Okumus I, Bascinar N (2001) The effect of different numbers of feeding days on feed consumption and growth of rainbow trout [Oncorhynchus mykiss (Walbaum)]. Aquaculture Research 32: 365-367.

20. Quartararo N (1996) Grow-out of snapper and mulloway in sea cages. In Quartararo N (ed.) Marine Finfish Farming Proceedings of a Workshop, 23 June 1995, NSW Fisheries Research Institute, Cronulla, NSW: 37-70.

21. Rimmer A, Ponia B (2007) A review of cage aquaculture: Oceania. Cage aquaculture - Regional reviews and global overview.

22. Guy J, Cowden K (2012) Re-invigorating NSW prawn farms through the culture of mulloway. Final Report PRJ-002273 to the Rural Industries Research and Development Corporation (RIRDC), RIRDC: 136.

23. Guy J, Cowden K (2014) Optimising mulloway farming through better feed and hatchery practices. RIRDC: 102.

24. Guy J, Cowden K (2015) Prawn hatchery modifications and adaptions for temperate marine fish culture in northern NSW, Australia. Aquacultural Engineering 67: 14-23.

25. Guy J, Mcllgorm A, Waterman P (2014) Aquaculture in regional Australia: Responding to trade externalities - a northern NSW case study. Journal of Economic and Social Policy 16: 1-29.

26. Guy J, Nottingham S (2014) Fillet yield, biochemical composition and consumer acceptance of farmed and wild mulloway. Journal Aquatic Food Product Technology 23: 608-620.

27. Daniel S (2004) Investigation into the nutritional requirements of juvenile dusky kob, Argyrosomus japonicus (Pisces: Sciaenidae), under ambient culture conditions. Thesis. Rhodes University, South Africa.

28. Fielder D, Ballagh D, Booth M, Pankhurst P, Becker C, Allan G (2010) Aquafin CRC project 1B5 : feed technology for temperate fish species, Vol. 1, feeding strategies. FRDC final report project No 2004/220 Industry and Investment NSW, Aquafin CRC and Fisheries Research and Development Corporation: 376.

29. Noga E (2010) Fish Disease: Diagnosis and Treatment (2ndedn) lowa: WileyBlackwell. Mulloway trials suggest opportunities for brackish water ponds, Austasia.

30. Jobling M, Johansen S (1999) The lipostat, hyperphagia and catch-up growth Aquaculture Research 30: 473-478.

31. Kapoor B, Smith H, Verighina I (1975) The alimentary canal and digestion in teleosts. Advances in Marine Biology 13: 109-239.

32. Buddington R, Krogdahl A, Bakke-McKellep A (1997) The intestines of carnivorous fish: structure and functions and the relations with diet. Acta Physiologica Scandinavica 638: 67-80.

33. Jobling M (1982) Some observations on the effects of feeding frequency on the food intake and growth of plaice, Pleuronectes platessa L. Journal of Fish Biology 20: 431-444.

34. Zaldúa N, Naya D (2014) Digestive flexibility during fasting in fish: A review. Comparative Biochemistry and Physiology Part A: Molecular \& Integrative Physiology 169: 7-14.

35. Ali M, Nicieza A, Wootton $R$ (2003) Compensatory growth in fishes: a response to growth depression. Fish and Fisheries 4: 147-190.

36. Li M, Manning B, Robinson E (2004) Effect of Daily Feed Intake on Feed Efficiency of Juvenile Channel Catfish. North American Journal of Aquaculture 66: 100-104. 
Citation: Guy JA, Stephen DA Smith (2016) Effects of Meal Frequency on Growth Performance and Feed Efficiency of Two year-Old Mulloway (Argyrosomus Japonicus; Pisces : Sciaenidae) Reared in Tanks. J Aquac Res Development. 7: 419. doi:10.4172/2155-9546.1000419

37. Li H, Robinson H, Bosworth G (2005) Effects of Periodic Feed Deprivation on Growth, Feed Efficiency, Processing Yield, and Body Composition of Channel Catfish Ictalurus punctatus. Journal of the World Aquaculture Society 36: 444-453.

38. EroldoĞAn O, Kumlu M, Kiris G, Sezer B (2006) Compensatory growth response of Sparus aurata following different starvation and refeeding protocols. Aquaculture Nutrition 12: 203-210.

39. Blanquet I, Oliva-Teles A (2010) Effect of feed restriction on the growth performance of turbot (Scophthalmus maximus L.) juveniles under commercial rearing conditions. Aquaculture Research 41: 1255-1260.

40. Hayward R, Noltie D, Wang N (1997) Use of compensatory growth to double hybrid sunfish growth rates. Transactions of the American Fisheries Society 126: 316-322.

41. Urbinati C, Sarmiento J, Takahashi S (2014) Short-term cycles of feed deprivation and refeeding promote full compensatory growth in the Amazon fish matrinxã (Brycon amazonicus). Aquaculture 433: 430-433.

42. Azodi M, Ebrahimi E, Farhadian O, Mahboobi-Soofiani N, Morshedi V, et al (2015) Compensatory growth response of rainbow trout Oncorhynchus mykiss Walbaum following short starvation periods. Chinese Journal of Oceanology and Limnology 33: 928-933.

43. Peterson B, Small B (2006) Effect of feeding frequency on feed consumption growth, and feed efficiency in aquarium-reared norris and NWAC103 channe catfish (Ictalurus punctatus). Journal of the World Aquaculture Society 37: 490-495.

44. Brett J, Grove T (1979) Physiological energetics, Physiology Bioenergetics and Growth, Academic Press, New York, 8: 279-352.

45. Hardy R (1998) Feed salmon and trout. Nutrition and Feeding of Fish, (2ndedn): Kluwer Academic Publishers, Boston, 175-197.
46. Guinea J, Fernandez F (1997) Effect of feeding frequency, feeding level and temperature on energy metabolism in Sparus aurata. Aquaculture 148: 125-142.

47. Elliott $J$ (1982) The effects of temperature and ration size on the growth and energetics of salmonids in captivity. Physio Comparative Biochemistry and Physiology Part B 73: 81-91.

48. Jobling M (1994) Fish Bioenergetics, Chapman and Hall, London.

49. Du Z, Liu Y, Tian L, He J, Cao J, et al. (2006) The influence of feeding rate on growth, feed efficiency and body composition of juvenile grass carp (Ctenopharyngodon idella). Aquaculture International 14: 247-257.

50. Henken A, Kleingeld D, Tijssen P (1985) The effect of feeding level on apparent digestibility of dietary dry matter, crude protein and gross energy in the African catfish Clarias gariepinus (Burchell, 1822). Aquaculture 51: 1-11.

51. Elliott J (1976) Energy losses in the waste products of brown trout (Salmo trutta L.). Journal of Animal Ecology 45: 561-580.

52. Kulczykowska E, Sánchez Vázquez F (2010) Neurohormonal regulation of feed intake and response to nutrients in fish: aspects of feeding rhythm and stress. Aquaculture Research 41: 654-667.

53. Sánchez A, López-Olmeda F, Blanco-Vives B, Sánchez-Vázquez J (2009) Effects of feeding schedule on locomotor activity rhythms and stress response in sea bream. Physiology and Behavior 98: 125-129.

54. El Sayed T, Monino A, Martínez S, Tomás A, Barrera R, et al. (2005) Effecto weekly feeding frequency in performance of Nile Tilapia. 10th National Congress of Aquaculture, Valencia, Spain.

55. Reigh R, Williams B, Jacob B (2006) Influence of repetitive periods of fasting and satiation feeding on growth and production characteristics of channe catfish, Ictalurus punctatus. Aquaculture 254: 506-516. 